\title{
Reactivity of $\left[\mathrm{Et}_{4} \mathrm{~N}\right]_{2}\left[\mathrm{MeSb}\left\{\mathrm{Fe}(\mathrm{CO})_{4}\right\}_{3}\right]$ toward HOAc and $\left[\mathrm{Cu}(\mathrm{MeCN})_{4}\right] \mathrm{BF}_{4}$ : formation of $\left[\mathrm{Et}_{4} \mathrm{~N}\right]\left[\mathrm{Me}(\mathrm{OAc}) \mathrm{Sb}\left\{\mathrm{Fe}(\mathrm{CO})_{4}\right\}_{2}\right]$ and $\left[\mathrm{MeSb}\left\{\mathrm{Fe}(\mathrm{CO})_{4}\right\}\left\{\mathrm{Fe}_{2}(\mathrm{CO})_{8}\right\}\right]$
}

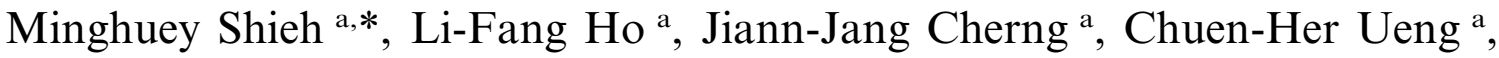 \\ Shie-Ming Peng ${ }^{b}$, Gene-Hsiang Lee ${ }^{c}$ \\ a Department of Chemistry, National Taiwan Normal University, Taipei 116, Taiwan, ROC \\ ${ }^{\mathrm{b}}$ Department of Chemistry, National Taiwan University, Taipei 107, Taiwan, ROC \\ ' Instrumentation Center, National Taiwan University, Taipei 107, Taiwan, ROC
}

Received 16 March 1999; received in revised form 18 May 1999

\begin{abstract}
Reactions of the tetrahedral methylantimony complex $\left[\mathrm{Et}_{4} \mathrm{~N}\right]_{2}\left[\mathrm{MeSb}\left\{\mathrm{Fe}(\mathrm{CO})_{4}\right\}_{3}\right]$ with $\mathrm{HOAc}$ and $\left[\mathrm{Cu}(\mathrm{MeCN})_{4}\right]\left[\mathrm{BF}{ }_{4}\right]$ were investigated. While the reaction of $\left[\mathrm{Et}_{4} \mathrm{~N}\right]_{2}\left[\mathrm{MeSb}\left\{\mathrm{Fe}(\mathrm{CO})_{4}\right\}_{3}\right]$ with $\mathrm{HOAc}$ forms the substituted complex $\left[\mathrm{Et} t_{4} \mathrm{~N}\right][\mathrm{Me}(\mathrm{OAc})-$ $\left.\mathrm{Sb}\left\{\mathrm{Fe}(\mathrm{CO})_{4}\right\}_{2}\right]\left(\left[\mathrm{Et}_{4} \mathrm{~N}\right][\mathrm{I}]\right)$, the treatment with $\left[\mathrm{Cu}(\mathrm{MeCN})_{4}\right]\left[\mathrm{BF}_{4}\right]$ forms the oxidized product $\left[\mathrm{MeSb}\left\{\mathrm{Fe}(\mathrm{CO})_{4}\right\}\left\{\mathrm{Fe}_{2}(\mathrm{CO})_{8}\right\}\right](\mathrm{II})$. The structures of $\left[\mathrm{Et}_{4} \mathrm{~N}\right][\mathbf{I}]$ and $\mathbf{I I}$ are determined by single-crystal X-ray diffraction. [ $\left[\mathrm{Et}_{4} \mathrm{~N}\right][\mathbf{I}]$ crystallizes in the orthorhombic space group Pna2 ${ }_{1}$ with $a=16.627(4), b=9.411(3), c=17.347(4) \AA, V=2714(1) \AA^{3}$, and $Z=4$. The crystals of II are triclinic, space group $P \overline{1}$ with $a=9.335(1), b=10.313(3), c=10.372(1) \AA, \alpha=97.46(1), \beta=93.63(1), \gamma=94.65(1)^{\circ}, V=984.0(3) \AA^{3}$, and $Z=2$. Cluster $I$ is an OAc group substituted product which displays a tetrahedral metal core with the central antimony atom bonded to two $\mathrm{Fe}(\mathrm{CO})_{4}$ fragments, one Me group, and one OAc moiety. Compound II is the two-electron oxidized product of $\left[\mathrm{Et}_{4} \mathrm{~N}\right]_{2}\left[\mathrm{MeSb}\left\{\mathrm{Fe}(\mathrm{CO})_{4}\right\}_{3}\right]$ where one $\mathrm{Fe}-\mathrm{Fe}$ bond is formed upon the addition of $\left[\mathrm{Cu}(\mathrm{MeCN})_{4}\right]\left[\mathrm{BF}_{4}\right]$. The results are compared with those of the analogous bismuth system and the role of the main group elements is discussed as well. C) 1999 Elsevier Science S.A. All rights reserved.
\end{abstract}

Keywords: Antimony; Carbonyl; Iron; X-ray diffraction

\section{Introduction}

Main group-transition metal carbonyl clusters attract extensive attention due to their interesting bonding modes and reactivity patterns [1]. To understand the reactivity of metal clusters, their reactions towards acids [1] and oxidants such as $\left[\mathrm{Cu}(\mathrm{MeCN})_{4}\right] \mathrm{BF}_{4}[1,2]$ have been well documented. Recent study has shown that the role of the main group elements has significant influence on the reactivity of the mixed main grouptransition metal clusters [3]. We have been interested in the interaction of main group-transition metal clusters with organic moieties and have investigated the alkylations of the tetrahedral clusters $\left[\mathrm{Et}_{4} \mathrm{~N}\right]_{3}\left[\mathrm{E}\left\{\mathrm{Fe}(\mathrm{CO})_{4}\right\}_{4}\right]$

\footnotetext{
* Corresponding author. Fax: + 886-2-29324249.
}

$(\mathrm{E}=\mathrm{Bi}, \mathrm{Sb})$ with a series of alkyl halides [4]. The monoalkylated products $\left[\mathrm{Et}_{4} \mathrm{~N}\right]_{2}\left[\mathrm{RE}\left\{\mathrm{Fe}(\mathrm{CO})_{4}\right\}_{3}\right](\mathrm{E}=$ $\mathrm{Bi}, \mathrm{Sb})$ were obtained from these reactions. In the bismuth system, treatments of $\left[\mathrm{Et}_{4} \mathrm{~N}\right]_{2}\left[\mathrm{RBi}\left\{\mathrm{Fe}(\mathrm{CO})_{4}\right\}_{3}\right]$ with $\mathrm{HCl}$ (aq.) yielded the decomposed products; however, the reaction with the mild acid HOAc led to the cyclic complexes $\left[\mathrm{RBiFe}(\mathrm{CO})_{4}\right]_{2}$. On the other hand, the reactions of $\left[\mathrm{Et}_{4} \mathrm{~N}\right]_{2}\left[\mathrm{RBi}\left\{\mathrm{Fe}(\mathrm{CO})_{4}\right\}_{3}\right]$ with $[\mathrm{Cu}(\mathrm{Me}-$ $\left.\mathrm{CN})_{4}\right]\left[\mathrm{BF}_{4}\right]$ underwent severe bond breakage to give the decomposition products as well [4b]. To probe the effect of $\mathrm{HOAc}$ and $\left[\mathrm{Cu}(\mathrm{MeCN})_{4}\right]\left[\mathrm{BF}_{4}\right]$ and the role of the main group element in these reactions, we further investigated the reactions of the analogous monoalkylated antimony cluster $\left[\mathrm{Et}_{4} \mathrm{~N}\right]_{2}\left[\mathrm{MeSb}\left\{\mathrm{Fe}(\mathrm{CO})_{4}\right\}_{3}\right]$ with HOAc and $\left[\mathrm{Cu}(\mathrm{MeCN})_{4}\right]\left[\mathrm{BF}_{4}\right]$, which are compared with the outcome of the $\mathrm{Bi}-\mathrm{Fe}$ system. 


\section{Experimental}

\subsection{General methods}

All reactions were performed under an atmosphere of pure nitrogen using standard Schlenk techniques [5]. Solvents were purified, dried, and distilled under nitrogen prior to use. The compound $\left[\mathrm{Et}_{4} \mathrm{~N}\right]_{2}[\mathrm{Me}-$ $\left.\mathrm{Sb}\left\{\mathrm{Fe}(\mathrm{CO})_{4}\right\}_{3}\right]$ was prepared according to the published method [4c]. IR spectra were recorded on a PerkinElmer Paragon 500 spectrometer as solutions in $\mathrm{CaF}_{2}$ cells. The ${ }^{1} \mathrm{H}$ - and ${ }^{13} \mathrm{C}$-NMR spectra were taken on a Jeol $400(400 \mathrm{MHz})$ instrument. Elemental analyses were performed on a Perkin-Elmer 2400 analyzer at the NSC Regional Instrumental Center at National Taiwan University, Taipei, Taiwan.

\subsection{Reaction of $\left[\mathrm{Et}_{4} \mathrm{~N}\right]_{2}\left[\mathrm{MeSb}\left\{\mathrm{Fe}(\mathrm{CO})_{4}\right\}_{4}\right]$ with $\mathrm{HOAc}$}

To a sample of $0.792 \mathrm{~g} \quad(0.879 \mathrm{mmol})$ of $\left[\mathrm{Et}_{4} \mathrm{~N}\right]_{2}\left[\mathrm{MeSb}\left\{\mathrm{Fe}(\mathrm{CO})_{4}\right\}_{3}\right]$ was added $5.0 \mathrm{ml}$ of HOAc. The mixed solution was stirred and heated in an oil bath at $50^{\circ} \mathrm{C}$ for $65 \mathrm{~h}$. The solution was filtered and HOAc was then removed under vacuum, and the residue was then washed with hexanes and extracted with ether. The ether extract was recrystallized with ether/hexanes to give $0.21 \mathrm{~g}(0.317 \mathrm{mmol})$ of a yellowish orange product $\left[\mathrm{Et}_{4} \mathrm{~N}\right]\left[\mathrm{Me}(\mathrm{OAc}) \mathrm{Sb}\left\{\mathrm{Fe}(\mathrm{CO})_{4}\right\}_{2}\right]\left(\left[\mathrm{Et}_{4} \mathrm{~N}\right]-\right.$ [I]) $(36 \%)$. IR ( $v \mathrm{CO}, \mathrm{MeCN}): 2040 \mathrm{~m}, 2017 \mathrm{~s}, 1930 \mathrm{vs,}$

Table 1

Crystallographic data for $\left[\mathrm{Et}_{4} \mathrm{~N}\right]\left[\mathrm{Me}(\mathrm{OAc}) \mathrm{Sb}\left\{\mathrm{Fe}(\mathrm{CO})_{4}\right\}_{2}\right]\left(\left[\mathrm{Et}_{4} \mathrm{~N}\right][\mathrm{I}]\right)$ and $\left[\mathrm{MeSb}\left\{\mathrm{Fe}(\mathrm{CO})_{4}\right\}\left\{\mathrm{Fe}_{2}(\mathrm{CO})_{8}\right\}\right]$ (II)

\begin{tabular}{lll}
\hline & {$\left[\mathrm{Et}_{4} \mathrm{~N}\right][\mathbf{I}]$} & II \\
\hline Empirical formula & $\mathrm{C}_{19} \mathrm{H}_{26} \mathrm{Fe}_{2} \mathrm{NO}_{10} \mathrm{Sb} \mathrm{C}_{13} \mathrm{H}_{3} \mathrm{Fe}_{3} \mathrm{O}_{12} \mathrm{Sb}$ \\
& & \\
Formula weight & 641.69 & 640.44 \\
Crystal system & Orthorhombic & Triclinic \\
Space group & $P n a 2_{1}$ & $P \overline{1}$ \\
$a(\AA)$ & $16.627(4)$ & $9.335(1)$ \\
$b(\AA)$ & $9.411(3)$ & $10.313(3)$ \\
$c(\AA)$ & $17.347(4)$ & $10.372(1)$ \\
$\alpha\left({ }^{\circ}\right)$ & & $97.46(1)$ \\
$\beta\left({ }^{\circ}\right)$ & & $93.63(1)$ \\
$\gamma\left({ }^{\circ}\right)$ & $2714(1)$ & $94.65(1)$ \\
$V\left(\AA^{3}\right)$ & 4 & $984.0(3)$ \\
$Z$ & 1.570 & 2 \\
$D_{\text {calc }}\left(\mathrm{Mg} \mathrm{m}^{-3}\right)$ & 20.826 & 2.162 \\
Absorption coefficient & & 49.5 \\
$\quad\left(\mathrm{~cm}^{-1}\right)$ & $\mathrm{Nonius}(\mathrm{CAD} 4)$ & $\mathrm{Nonius}(\mathrm{CAD} 4)$ \\
Diffractometer & 0.7107 & 0.7107 \\
Radiation $(\lambda)\left(\mathrm{Mo}-\mathrm{K}_{\alpha}\right)$ & & \\
$\quad(\AA)$ & 25 & 25 \\
Temperature $\left({ }^{\circ} \mathrm{C}\right)$ & $0.78 / 1.00$ & $0.44 / 1.00$ \\
$T_{\text {min }} / T_{\text {max }}$ & $0.033,0.031$ & $0.027,0.029$ \\
Residuals, $R{ }^{\text {a }}, R w^{\text {a }}$ & & \\
& &
\end{tabular}

a The functions minimized during least-squares cycles were $R=$ $\Sigma\left|F_{\mathrm{o}}-F_{\mathrm{c}}\right| / \Sigma F_{\mathrm{o}}$ and $R w=\left[\Sigma w\left(F_{\mathrm{o}}-F_{\mathrm{c}}\right)^{2} / \Sigma w\left(F_{\mathrm{o}}\right)^{2}\right]^{1 / 2}$. br $\mathrm{cm}^{-1} .{ }^{1} \mathrm{H}-\mathrm{NMR}\left(400 \mathrm{MHz}, \mathrm{DMSO}-d_{6}, 298 \mathrm{~K}\right.$ ): $\delta$ $1.61(\mathrm{~s}, 3 \mathrm{H}), 1.73(\mathrm{~s}, 3 \mathrm{H})$ (chemical shifts not given for $\left.\left[\mathrm{Et}_{4} \mathrm{~N}\right]^{+}\right)$. Anal. Calc. for $\left[\mathrm{Et}_{4} \mathrm{~N}\right][\mathrm{Me}(\mathrm{OAc}) \mathrm{Sb}\{\mathrm{Fe}-$ $\left.(\mathrm{CO})_{4}\right\}_{2}$ ]: C, 34.48; H, 3.96; N, 2.12. Found: C, 34.35; $\mathrm{H}, 3.75 ; \mathrm{N}, 2.05 \%$.

\subsection{Reaction of $\left[\mathrm{Et}_{4} \mathrm{~N}_{2}\left[\mathrm{MeSb}\left\{\mathrm{Fe}(\mathrm{CO})_{4}\right\}_{4}\right]\right.$ with $\left[\mathrm{Cu}(\mathrm{MeCN})_{4}\right]\left[\mathrm{BF}_{4}\right]$}

To a solution of $0.630 \quad \mathrm{~g} \quad(0.70 \mathrm{mmol})$ of $\left[\mathrm{Et}_{4} \mathrm{~N}\right]_{2}\left[\mathrm{MeSb}\left\{\mathrm{Fe}(\mathrm{CO})_{4}\right\}_{3}\right]$ in $30 \mathrm{ml}$ of THF was added $0.458 \mathrm{~g}(1.46 \mathrm{mmol})$ of $\left[\mathrm{Cu}(\mathrm{MeCN})_{4}\right]\left[\mathrm{BF}_{4}\right]$. The mixed solution was stirred at room temperature for $63 \mathrm{~h}$. The solution was filtered, the solvent was removed under vacuum, and the residue was then extracted with hexanes. The hexanes extract was chromatographed using hexanes as eluent to give the greenish brown product which was recrystallized with ether/hexanes to give 0.11 g $(0.17 \mathrm{mmol})$ of yellowish orange complex $\left[\mathrm{MeSb}\left\{\mathrm{Fe}(\mathrm{CO})_{4}\right\}\left\{\mathrm{Fe}_{2}(\mathrm{CO})_{8}\right\}\right]$ (II) $(25 \%)$. IR $(v \mathrm{CO}$, hexanes): $2106 \mathrm{~m}, 2061 \mathrm{~s}, 2039 \mathrm{~s}, 2028 \mathrm{~s}, 2010 \mathrm{w}, \mathrm{sh}, 1975$ w, $1944 \mathrm{~m}$, br cm ${ }^{-1}$. ${ }^{1} \mathrm{H}-\mathrm{NMR}\left(400 \mathrm{MHz}, \mathrm{CDCl}_{3}, 298\right.$ $\mathrm{K}): \delta 2.34(\mathrm{~s}, 3 \mathrm{H}) \cdot{ }^{13} \mathrm{C}-\mathrm{NMR}\left(100 \mathrm{MHz}, \mathrm{CDCl}_{3}, 298\right.$ $\mathrm{K}): \delta$ 6.37, 206.3, 213.4. Anal. Calc. for [MeSb $\{\mathrm{Fe}-$ $\left.\left.(\mathrm{CO})_{4}\right\}\left\{\mathrm{Fe}_{2}(\mathrm{CO})_{8}\right\}\right]$ : C, 24.38; H, 0.47. Found: C, 24.52; H, 0.48. M.p. $104^{\circ} \mathrm{C}$ (dec.).

\section{4. $X$-ray structural characterization of complexes $\left[E t_{4} N\right][\mathbf{I}]$ and $\mathbf{I I}$}

A summary of selected crystallographic data for $\left[\mathrm{Et}_{4} \mathrm{~N}\right][\mathbf{I}]$ and $\mathbf{I I}$ is given in Table 1. All crystals were mounted on glass fibers with Epoxy cement. Data collection was carried out on a Nonius CAD4 diffractometer using graphite-monochromated $\mathrm{Mo}-\mathrm{K}_{\alpha}$ radiation at $25^{\circ} \mathrm{C}$. A $\psi$ scan absorption correction was made [6]. Data reduction and structural refinement were performed using the NRCC-SDP-VAX packages [7], and atomic scattering factors were taken from the International Tables for X-ray Crystallography [8].

Structures of $\left[\mathrm{Et}_{4} \mathrm{~N}\right][\mathbf{I}]$ and II. The orange crystal of $\left[\mathrm{Et}_{4} \mathrm{~N}\right][\mathbf{I}]$ chosen for diffraction measurement was ca. $0.10 \times 0.45 \times 0.55 \mathrm{~mm}$, and brown crystal II had dimensions $0.50 \times 0.20 \times 0.15 \mathrm{~mm}$. Cell parameters were obtained from 25 reflections with $2 \theta$ angle in the range $19.00-26.10^{\circ}$ for $\left[\mathrm{Et}_{4} \mathrm{~N}\right][\mathbf{I}]$, and $23.38^{\circ}<2 \theta<32.48^{\circ}$ for II. A total of 1867 reflections with $I>2.0 \sigma(I)$ for $\left[\mathrm{Et}_{4} \mathrm{~N}\right][\mathbf{I}]$ (3060 reflections with $I>2.5 \sigma(I)$ for II) were used in the refinement. The structures were solved by the heavy atom method and refined by least-squares cycles. All the non-hydrogen atoms were refined with anisotropic temperature factors. Full-matrix leastsquares refinement led to convergence with $R=3.3$ and $R w=3.1 \%$ for $\left[\mathrm{Et}_{4} \mathrm{~N}\right][\mathbf{I}]$, and with $R=2.7$ and $R w=$ $2.9 \%$ for II. 
Table 2

Selected bond distances $(\AA)$ and bond angles $\left(^{\circ}\right)$ for $\left[\mathrm{Et}_{4} \mathrm{~N}\right]\left[\mathrm{Me}(\mathrm{OAc}) \mathrm{Sb}\left\{\mathrm{Fe}(\mathrm{CO})_{4}\right\}_{2}\right]\left(\left[\mathrm{Et}_{4} \mathrm{~N}\right][\mathrm{I}]\right)$
Bond distances

$\mathrm{Sb}-\mathrm{Fe}(1)$

$\mathrm{Sb}-\mathrm{C}(9)$

$\mathrm{C}(10)-\mathrm{O}(9)$

$$
\begin{aligned}
& 2.509(2) \\
& 2.151(8)
\end{aligned}
$$

$\mathrm{Sb}-\mathrm{Fe}(2)$

$\mathrm{Sb}-\mathrm{O}(9)$

C(10)-O(10)

$2.505(2)$

$2.077(6)$

1.34 (1)

$131.55(5)$

$107.4(2)$

$\mathrm{Fe}(1)-\mathrm{Sb}-\mathrm{C}(9)$

$\mathrm{Fe}(2)-\mathrm{Sb}-\mathrm{C}(9)$

$106.2(2)$

$\mathrm{Fe}(1)-\mathrm{Sb}-\mathrm{Fe}(2)$

107.2(2)
$\mathrm{Fe}(2)-\mathrm{Sb}-\mathrm{O}(9)$ tion of the OAc-substituted tetrahedral complex $\left[\mathrm{Et}_{4} \mathrm{~N}\right]\left[\mathrm{Me}(\mathrm{OAc}) \mathrm{Sb}\left\{\mathrm{Fe}(\mathrm{CO})_{4}\right\}_{2}\right] \quad\left(\left[\mathrm{Et}_{4} \mathrm{~N}\right][\mathbf{I}]\right)$ instead of forming the corresponding antimony cyclic complex $\left[\mathrm{MeSb}\left\{\mathrm{Fe}(\mathrm{CO})_{4}\right\}\right]_{2}$.

In the bismuth case, the formation of $\left[\mathrm{RBi}\left\{\mathrm{Fe}(\mathrm{CO})_{4}\right\}\right]_{2}$ is proposed to result from the dimerization of $\mathrm{RBi}\{\mathrm{Fe}(\mathrm{CO})\}_{4}$ derived from $[\mathrm{RBi}\{\mathrm{Fe}-$ $\left.\left.(\mathrm{CO})_{4}\right\}_{3}\right]^{2-}$. This study indicates that, in the antimony case, the $\mathrm{OAc}^{-}$group behaves more importantly as a nucleophile toward the central antimony atom, presumably in the +5 oxidation state, to replace one $\mathrm{Fe}(\mathrm{CO})_{4}$ group to form cluster $\mathbf{I}$. This difference is intriguing and could be attributed to the stronger $\mathrm{Sb}-\mathrm{O}$ versus $\mathrm{Bi}-\mathrm{O}$ bond, which results in the formation of the four-coordinated antimony product $\mathbf{I}$ in the $\mathrm{Sb}$ case rather than undergoing further fragmentation and dimerization to give the ring complex as in the $\mathrm{Bi}$ system. The result may suggest that the $\mathrm{OAc}^{-}$might ligate to the bismuth atom in the $\mathrm{Bi}-\mathrm{Fe}$ system to form the reactive species $\left[\mathrm{R}(\mathrm{OAc}) \mathrm{Bi}\left\{\mathrm{Fe}(\mathrm{CO})_{4}\right\}_{2}\right]^{-}$followed by acetate removal, $\mathrm{Bi}-\mathrm{Fe}$ bond breakage, and dimerization to give the cyclic complexes.
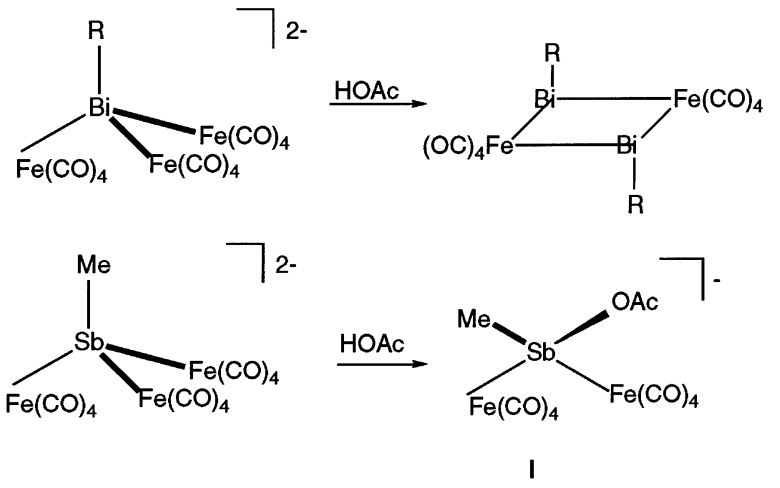

It has been shown that most metal clusters can be oxidized by $\left[\mathrm{Cu}(\mathrm{MeCN})_{4}\right] \mathrm{BF}_{4}$ to cause metal-metal bond formation or metal-vertex loss to give rise to the oxidized products. However, the extent of oxidation is mainly dependent on the nature of the metal-metal bonds [2]. In the bismuth case, the monoalkylated bismuth compounds $\left[\mathrm{Et}_{4} \mathrm{~N}\right]_{2}\left[\mathrm{RBi}\left\{\mathrm{Fe}(\mathrm{CO})_{4}\right\}_{3}\right]$ with $\left[\mathrm{Cu}(\mathrm{MeCN})_{4}\right] \mathrm{BF}_{4}$ induced severe bond breakage/formation to give the decomposed complexes [4b]. In this study, if $\left[\mathrm{Et}_{4} \mathrm{~N}\right]_{2}\left[\mathrm{MeSb}\left\{\mathrm{Fe}(\mathrm{CO})_{4}\right\}_{3}\right]$ was treated with two equivalents of $\left[\mathrm{Cu}(\mathrm{MeCN})_{4}\right] \mathrm{BF}_{4}$, one $\mathrm{Fe}-\mathrm{Fe}$ bond was formed to give the tetrahedral neutral complex $\left[\mathrm{MeSb}\left\{\mathrm{Fe}(\mathrm{CO})_{4}\right\}\left\{\mathrm{Fe}_{2}(\mathrm{CO})_{8}\right\}\right]$ (II). Compound II is obviously the two-electron oxidized product of the tetrahedral dianionic compound $\left[\mathrm{Et}_{4} \mathrm{~N}\right]_{2}\left[\mathrm{MeSb}\left\{\mathrm{Fe}(\mathrm{CO})_{4}\right\}_{3}\right]$. Again, the differing outcomes could be ascribed to the stronger $\mathrm{Sb}-\mathrm{R}$ and $\mathrm{Sb}-\mathrm{Fe}$ bonds compared with those in bismuth system due to the smaller size of $\mathrm{Sb}$ versus $\mathrm{Bi}$. 


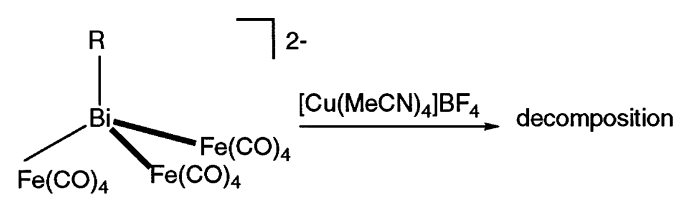

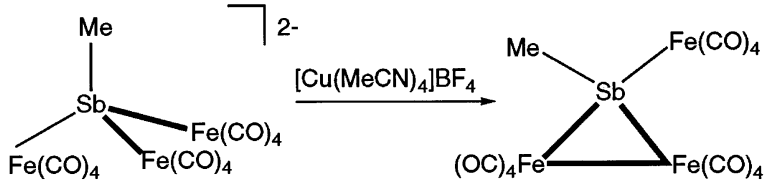

II

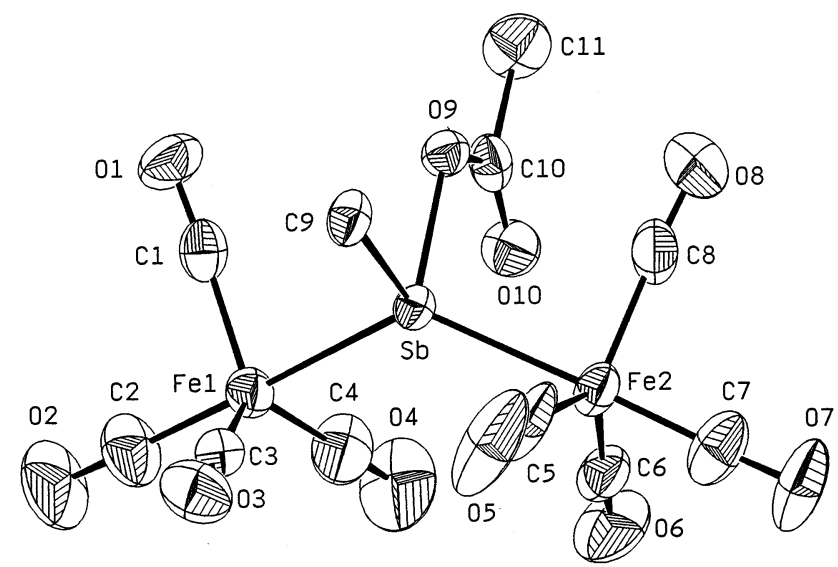

Fig. 1. ORTEP diagram showing the structure and atom labeling for $\mathbf{I}$.

\subsection{Structures of complexes $\left[E t_{4} N\right][\mathbf{I}]$ and $\boldsymbol{I I}$}

As shown in Figs. 1 and 2, the antimony atoms in the clusters I and II are in the distorted tetrahedral environment. This type of structure is seen in some $\mathrm{Sb}-\mathrm{Fe}$ carbonyl clusters [4c,11] and clusters I and II provide the new additions to this family. For comparison, the average $\mathrm{Fe}-\mathrm{Sb}-\mathrm{Fe}$ angle (without $\mathrm{Fe}-\mathrm{Fe}$ bonds), the $\mathrm{Sb}-\mathrm{Fe}$ distance, and the $\mathrm{Sb}-\mathrm{C}$ length of the related tetrahedral clusters are listed in Table 4. As shown in Table 4, the $\mathrm{Sb}-\mathrm{C}$ lengths are close to the sum of single bond covalent radii $(2.2 \AA)$ [12] and compared well with those in the related clusters [4c]. The Sb-Fe distances in I and II are in the range of other known $\mathrm{Sb}-\mathrm{Fe}(\mathrm{CO})_{4}$ distances $(2.460-2.715 \AA)[11,13,14]$ and are compared to those found in other structurally characterized antimony complexes such as $\left[\mathrm{ClSb}\left\{\mathrm{Fe}(\mathrm{CO})_{2} \mathrm{Cp}\right\}_{3}\right]_{2}^{2+}(2.539$ $\AA$, average) [15] and $\left[\mathrm{Cl}_{2} \mathrm{Sb}\left\{\mathrm{Fe}(\mathrm{CO})_{2} \mathrm{Cp}\right\}_{2}\right]^{+}(2.440 \AA$, average) [16].

The $\mathrm{Fe}-\mathrm{Sb}-\mathrm{Fe}$ angle $\left(131.55(5)^{\circ}\right)$ in cluster $\mathbf{I}$ is greater than the corresponding angles in $\left[\mathrm{Me}_{2} \mathrm{Sb}\right.$ $\left.\left\{\mathrm{Fe}(\mathrm{CO})_{4}\right\}_{2}\right]^{-}\left(123.95(4)^{\circ}\right)$ and $\left[\mathrm{MeISb}\left\{\mathrm{Fe}(\mathrm{CO})_{4}\right\}_{2}\right]^{-}$ $\left(122.20(7)^{\circ}\right)[4 c, 11 b]$. This is caused by the less steric hindrance of the OAc group than the Me or I fragment because in cluster I the OAc group is almost perpendicular to the $\mathrm{Fe}-\mathrm{Sb}-\mathrm{Fe}$ plane. For the monosubstituted $\mathrm{Sb}-\mathrm{Fe}$ clusters, the average $\mathrm{Fe}(1)-\mathrm{Sb}-\mathrm{Fe}(2)$ angle $\left(128.98^{\circ}\right)$ in $\mathbf{~ I I}$ is significantly greater than that in $\left[\mathrm{MeSb}\left\{\mathrm{Fe}(\mathrm{CO})_{4}\right\}_{3}\right]^{2-}\left(114.43^{\circ}\right)$. This is attributable to the existence of an $\mathrm{Fe}_{2}(\mathrm{CO})_{8}$ moiety that contains an $\mathrm{Fe}-\mathrm{Fe}$ bond. Moreover, cluster II is structurally related to the previously reported cluster $\left[\mathrm{SbFe}_{4}(\mathrm{CO})_{16}\right]^{-}[14 \mathrm{a}]$, in which the tetrahedral $\mathrm{Sb}$ atom is bonded to two $\mathrm{Fe}(\mathrm{CO})_{4}$ fragments and the $\mathrm{Fe}_{2}(\mathrm{CO})_{8}$ moiety. The acute $\mathrm{Fe}-\mathrm{Sb}-\mathrm{Fe}$ angle (with $\mathrm{Fe}-\mathrm{Fe}$ bond) in II $\left(67.83(3)^{\circ}\right)$ is greater than the corresponding angle of

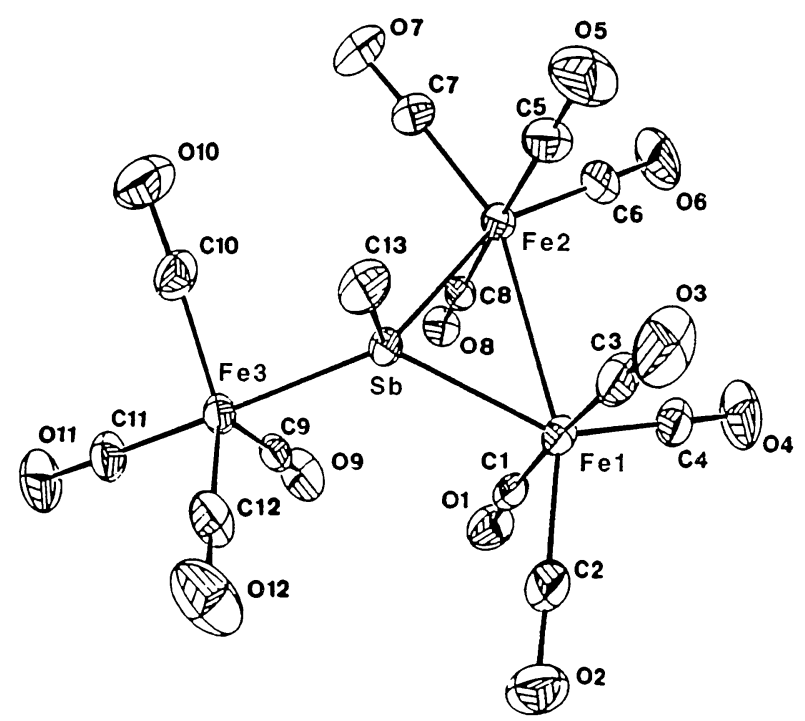

Fig. 2. ORTEP diagram showing the structure and atom labeling for II.

Table 4

Comparison of the average $\mathrm{Fe}-\mathrm{Sb}-\mathrm{Fe}$ angle (without $\mathrm{Fe}-\mathrm{Fe}$ bonds) and the average $\mathrm{Sb}-\mathrm{Fe}$ and $\mathrm{Sb}-\mathrm{C}$ distances in the related clusters

\begin{tabular}{|c|c|c|c|c|}
\hline Compounds & $\mathrm{Fe}-\mathrm{Sb}-\mathrm{Fe}$ angle $\left({ }^{\circ}\right)$ & $\mathrm{Sb}-\mathrm{Fe}(\AA)$ & $\mathrm{Sb}-\mathrm{C}(\AA)$ & Ref. \\
\hline$\left[\mathrm{Et}_{4} \mathrm{~N}\right]_{3}\left[\mathrm{Sb}\left\{\mathrm{Fe}(\mathrm{CO})_{4}\right\}_{4}\right]$ & 109.56 & 2.666 & - & [11a] \\
\hline$\left[\mathrm{Et}_{4} \mathrm{~N}\right]_{2}\left[\mathrm{MeSb}\left\{\mathrm{Fe}(\mathrm{CO})_{4}\right\}_{3}\right]$ & 114.43 & 2.614 & $2.160(7)$ & {$[4 \mathrm{c}]$} \\
\hline$[\mathrm{PPN}]\left[\mathrm{MeISb}\left\{\mathrm{Fe}(\mathrm{CO})_{4}\right\}_{2}\right]$ & $122.20(7)$ & $2.508(1)$ & - & {$[11 \mathrm{~b}]$} \\
\hline$\left[\mathrm{Me}_{4} \mathrm{~N}\right]\left[\mathrm{SbFe}_{4}(\mathrm{CO})_{16}\right]$ & 113.13 & 2.603 & - & [14a] \\
\hline$\left[\mathrm{Et}_{4} \mathrm{~N}\right][\mathbf{I}]$ & $131.55(5)$ & 2.507 & $2.151(8)$ & This work \\
\hline
\end{tabular}


$\left[\mathrm{SbFe}_{4}(\mathrm{CO})_{16}\right]^{-}\left(62.09(3)^{\circ}\right)$ due to the smaller steric hindrance of the methyl group than the $\mathrm{Fe}(\mathrm{CO})_{4}$ group.

Finally, in cluster $\mathbf{I}$, the acetato ligand OAc binds to the $\mathrm{Sb}$ atom in the $\eta^{1}$-fashion and this type of bonding mode is less seen than the commonly observed $\eta^{2}$-OAc in the diruthenium complexes such as $\left[\mathrm{Ru}_{2}(\mathrm{CO})_{4-}\right.$ $\left.\left(\mu-\mathrm{O}_{2} \mathrm{CR}\right)(\mathrm{DPPM})_{2}\right]^{+}, \quad\left[\mathrm{Ru}_{2}(\mathrm{CO})_{4}\left(\mu-\mathrm{O}_{2} \mathrm{CR}\right)(\mathrm{DPPE})_{2}\right]^{+}$, $\left[\mathrm{Ru}_{2}\left(\mu-\mathrm{Pz}^{\prime}\right)\left(\mu-\mathrm{O}_{2} \mathrm{CMe}\right)(\mathrm{CO})_{4}\left(\mathrm{HPz}^{\prime}\right)_{2}\right]$, and $\left[\mathrm{Ru}_{2}\left(\mu-\mathrm{Pz}^{\prime}\right)(\mu-\right.$ $\left.\left.\mathrm{O}_{2} \mathrm{CMe}\right)(\mathrm{CO})_{4}\left(\mathrm{PPh}_{3}\right)_{2}\right]$ [10]. It is noted that the $\mathrm{C}(10)-\mathrm{O}(10)$ distance $(1.19(1) \AA)$ is significantly shorter than that (1.34 (1) $\AA$ ) of $\mathrm{C}(10)-\mathrm{O}(9)$, the one involving bonding to $\mathrm{Sb}$, due to the chelating effect.

\section{Summary}

The reaction of $\left[\mathrm{Et}_{4} \mathrm{~N}\right]_{2}\left[\mathrm{MeSb}\left\{\mathrm{Fe}(\mathrm{CO})_{4}\right\}_{3}\right]$ with HOAc forms the OAc substituted cluster I while treatment with $\left[\mathrm{Cu}(\mathrm{MeCN})_{4}\right] \mathrm{BF}_{4}$ produces cluster II. These results are somewhat different from those of the corresponding reactions in the $\mathrm{Bi}-\mathrm{Fe}$ system due to the smaller size and larger basicity of the antimony versus the bismuth atom.

\section{Supplementary material}

Additional crystallographic data of $\left[\mathrm{Et}_{4} \mathrm{~N}\right][\mathbf{I}]$ and II are available from the authors.

\section{Acknowledgements}

We thank the National Science Council of the Republic of China for financial support (NSC87-2113-M003-001).

\section{References}

[1] For recent reviews of transition-metal/main-group compounds, see: (a) W.A. Herrmann, Angew. Chem. Int. Ed. Engl. 25 (1986) 56. (b) M.D. Vaira, P. Stoppioni, M. Peruzzini, Polyhedron 6 (1987) 351. (c) O.J. Scherer, Comments Inorg. Chem. 6 (1987) 1. (d) O.J. Scherer, Angew. Chem. Int. Ed. Engl. 24 (1985) 924. (e) K.H. Whitmire, J. Coord. Chem. 17 (1988) 95. (f) G. Huttner, K. Knoll, Angew. Chem. Int. Ed. Engl. 26 (1987) 743. (g) G. Huttner, K. Evertz, Acc. Chem. Res. 19 (1986) 406. (h) H.
Vahrenkamp, Adv. Organomet. Chem. 22 (1983) 169. (i) A.H. Cowley, J. Organomet. Chem. 400 (1990) 71. (j) A.-J. Dimaio, A.L. Rheingold, Chem. Rev. 90 (1990) 169. (k) K.H. Whitmire, J. Clust. Sci. 2 (1991) 231. (1) K.H. Whitmire, Adv. Organomet. Chem. 42 (1997) 1. (m) P. Mathur, Adv. Organomet. Chem. 41 (1997) 243. (n) M. Shieh, J. Clust. Sci. 10 (1999) 3.

[2] (a) C.B. Lagrone, K.H. Whitmire, M.R. Churchill, J.C. Fettinger, Inorg. Chem. 25 (1986) 2080. (b) K.H. Whitmire, M. Shieh, C.B. Lagrone, B.H. Robinson, M.R. Churchill, J.C. Fettinger, R.F. See, Inorg. Chem. 26 (1987) 2798. (c) K.H. Whitmire, C.B. Lagrone, M.R. Churchill, J.C. Fettinger, B.H. Robinson, Inorg. Chem. 26 (1987) 3491.

[3] (a) L.E. Bogan, Jr., T.B. Rauchfuss, A.L. Rheingold, J. Am. Chem. Soc. 107 (1985) 3843. (b) L.E. Bogan, Jr., G.R. Clark, T.B. Rauchfuss, Inorg. Chem. 25 (1986) 4050. (c) M. Shieh, T.-F. Tang, S.-M. Peng, G.-H. Lee, Inorg. Chem. 34 (1995) 2797 and Refs. therein.

[4] (a) M. Shieh, Y. Liou, S.-M. Peng, G.-H Lee, Inorg. Chem. 32 (1993) 2212. (b) M. Shieh, Y. Liou, B.-W. Jeng, Organometallics 12 (1993) 4926. (c) M. Shieh, C-M. Sheu, L.-F. Ho, J.-J. Cherng, L.-F. Jang, C.-H. Ueng, Inorg. Chem. 35 (1996) 5504.

[5] D.F. Shriver, M.A. Drezdon, The Manipulation of Air Sensitive Compounds, Wiley, New York, 1986.

[6] A.C.T. North, D.C. Philips, F.S. Mathews, Acta Crystallogr. Sect. A 24 (1968) 351.

[7] E.J. Gabe, Y. Lepage, J.P. Charland, F.L. Lee, P.S. White, J. Appl. Crystallogr. 22 (1989) 384.

[8] International Tables for X-ray Crystallography, vol. IV, Kynoch Press, Birmingham, UK, 1974.

[9] G.R. Crook, B.F.G. Johnson, J. Lewis, I.G. Williams, G. Gamlen, J. Chem. Soc. A (1969) 2761.

[10] (a) W.G. Klemperer, B. Zhong, Inorg. Chem. 32 (1993) 5821. (b) S.J. Sherlock, M. Cowie, E. Singleton, M.M. de V. Steyn, Organometallics 7 (1988) 1663. (c) K.-B. Shiu, C.-H. Li, T.-J. Chan, S.-M. Peng, M.-C. Cheng, S.-L. Wang, F.-L. Liao, M.Y. Chiang, Organometallics 14 (1995) 524. (d) K.-B. Shiu, W.-M. Lee, C.-L. Wang, S.-L. Wang, F.-L. Liao, J.-C. Wang, L.-S. Liou, S.-M. Peng, G.-H. Lee, M.Y. Chiang, Organometallics 15 (1996) 2979.

[11] (a) S. Luo, K.H. Whitmire, Inorg. Chem. 28 (1989) 1424. (b) J.W. van Hal, J.L. Stark, K.H. Whitmire, J. Organomet. Chem. 557 (1998) 163.

[12] J.E. Huheey, E.A. Keiter, R.L. Keiter, Inorganic Chemistry: Principles of Structure and Reactivity, Harper Collins College Publishers, New York, 1993

[13] (a) A.H. Cowley, N.C. Norman, M. Pakulski, D.L. Bricker, D.H. Russell, J. Am. Chem. Soc. 107 (1985) 8211. (b) A.M. Arif, AH. Cowley, M. Pakulski, J. Chem. Soc. Chem. Commun. (1987) 622.

[14] (a) S. Luo, K.H. Whitmire, J. Organomet. Chem. 376 (1989) 297. (b) K.H. Whitmire, J.S. Leigh, S. Luo, M. Shieh, M.D. Fabiano, New J. Chem. 12 (1988) 397. (c) A.L. Rheingold, S.J. Gieb, M. Shieh, K.H. Whitmire, Inorg. Chem. 26 (1987) 463.

[15] Trinh-Toan, L.F. Dahl, J. Am. Chem. Soc. 93 (1971) 2654.

[16] F.W.B. Einstein, R.D.G. Jones, Inorg. Chem. 12 (1973) 1690. 